\title{
A pénzügyi, biztosítási tevékenység nemzetgaz- dasági ág értékesítőinek ágazatok közötti átjárhatóságvizsgálata
}

\author{
Juhász István \\ Eszterházy Károly Egyetem
}

\section{A TANULMÁNY CÉLJA}

A tanulmány alapvető célja, hogy bebizonyítsa a pénzügyi, biztosítási tevékenység nemzetgazdasági ágban dolgozó értékesítők egy 1000 fős mintáján végzett vizsgálata alapján a bank, a biztosítás, a lakástakarékpénztár és a pénzügyi tanácsadás ágazataiban dolgozó értékesítők személyisége a Kaliforniai Pszichológiai Kérdőív rövidített verziójának eredményei alapján eltér egymástól (H1 hipotézis).

\section{ALKALMAZOTT MÓDSZERTAN}

A vizsgálat alanyai a jelenleg pénzügyi területen, azon belül is értékesítői munkakörben dolgozó munkavállalók közül azok, akik elsősorban a bankokban, biztosítóknál, lakástakarékpénztárakban, pénzügyi tanácsadóknál tevékenykednek. A vizsgálati alanyok on-line az internet segítségével töltötték ki a kérdöíveket. A mintavétel a nem véletlen mintavételi eljárások közül, a hólabda-mintavételi eljárás révén történt. A begyüjtött adatok elemzése és kiértékelése az SPSS program segítségével zajlott, melynek használata során az adatokon diszkriminanciaelemzés került lefuttatásra.

\section{LEGFONTOSABB EREDMÉNYEK}

A vizsgált, pénzügyi területen dolgozó üzletkötők mintáján végzett diszkriminanciaelemzés során kapott diszkriminanciafüggvények a véletlennél nagyobb valószínűséggel képesek előre jelezni, hogy az egyes üzletkötők melyik ágazatban dolgoznak. A vizsgálati eredmények tükrében azonban nincs olyan jelentős eltérés a pénzügyi, biztositási tevékenység nemzetgazdasági ág egyes ágazataiban foglalkoztatott üzletkötőinek - a Kaliforniai Pszichológiai Kérdőív rövidített verziójával történt felmérés eredményei alapján feltérképezett - személyisége között, mely megakadályozná, hogy azok más ágazatokban is alkalmazásra kerüljenek.

\section{GYAKORLATI JAVASLATOK}

A kutatási eredmények alapján javaslom, hogy a pénzügyi területen tevékenykedő értékesítők kiválasztásában részt vevő HR vezetők, kiválasztási szakemberek, vállalati döntéshozók fontolják meg, hogy a pénzügyi, biztosítási tevékenység nemzetgazdasági ág egy másik ágazatában már bizonyított üzletkötőt felvegyenek és alkalmazzanak vállalatuknál (amennyiben más kiválasztási kritériumoknak is megfelel), mivel a kérdőívben elért eredmények alapján nincs számottevő különbség az egyes ágazatok üzletkötőinek személyisége között.

Kulcsszavak: Pénzügy, értékesítők, személyiség, munkaerő-kiválasztás, alkalmasság-vizsgálat

DOI: 10.15170/MM.2021.55.02.07 


\section{BEVEZETÉS INTRODUCTION}

Vajon a pénzügyi, biztosítási tevékenység nemzetgazdasági ág egyes ágazataiban dolgozó értékesítők egy másik ágazatban is megtalálnák számításaikat? A pénzügyi szervezeteknek érdeke a lehető legalkalmasabb emberek kiválasztása, míg az ott foglalkoztatott értékesítőknek - általában - a személyiségüknek leginkább megfelelő munkakör felismerése és ezt a munkakört a számukra legmegfelelőbb módon biztosító pénzügyi vállalkozásnak, cégnek egyéb szervezetnek a megtalálása a munkaerőpiacon (Juhász 2019a, 65) Felnőtt emberként többségünknek már van személyes tapasztalata a pénzügyi területen dolgozó üzletkötőkkel. Ha végig gondoljuk, akkor rá kell döbbenünk, hogy sokszor teljesen eltérő személyiséggel bír a pénzügyi tanácsadónk, a brókerünk, a biztosítási vagy éppen a banki szakemberünk. A hazai értékesítők személyiségét is kutató Bauer - Mitev szerzőpáros a következő nagyon találó hasonlattal jellemzi az értékesítői szakmát: „az értékesítés tehát valójában egy gyüjtőszakma, amely a vízgyüjtő területekhez hasonlóan begyüjti azokat az egyéneket is, akik épp nem találnak maguknak szakmát vagy legalábbis nem annyira tudatosak saját sorsuk meghatározásában. Mint ahogy a vízgyüjtő területek aktivitása élénkebbé válik akkor, amikor nagyobb mennyiségủ csapadék hullik le, úgy lesz erősebb az értékesítési szakma vonzereje, ha gazdasági viharok, vagy egy-egy szakterületen gyülemlő problémafelhők száma megnő.” (Bauer \& Mitev 2016, 34).

Nemzetközi szinten elmondható, hogy a globalizáció hatásaként egyre több és több külföldi munkavállalóval találkozunk mindennapjaink során, és itt már nem csak a kereskedelmi üzletekre és éttermekre kell gondolni, hanem más egyéb szolgáltatásokat nyújtó intézményekre (nyelviskolákra, bankokra, egészségügyi intézményekre) (Juhász 2014a). Meg kell jegyezni továbbá, hogy a jövőben az Egyesült Államoknak és Európának tehát nemcsak azzal kell számolnia, hogy országaikban még inkább megjelennek a külföldi vállalkozások, hanem azzal is, hogy ezen vállalkozásokkal együtt egy fiatal, szorgalmas, kreatív munkavállalói csoport is feltünik a munkaerőpiacon (Juhász 2014b). Akár a pénzügyi, biztosítási tevékenység nemzetgazdasági ágban is.

Véleményem szerint ezen „gyüjtőszakma” képviselőinek sikere vagy éppen sikertelensége saját személyiségükből fakad. Jelen tanulmány alapvető célja egy olyan összehasonlító elemzés elvégzése, mely bebizonyítja, hogy jelentős különbség van a pénzügyi, biztosítási tevékenység nemzetgazdasági ág egyes ágazataiban foglalkoztatott értékesítők között, megkönnyítve ezen szakemberek kiválasztását az üzletkötői álláshirdetésekre jelentkezők közül (Juhász 2019b). Teszi mindezt a Kaliforniai Pszichológiai Kérdőív rövidített (angolul Shortened California Psychological Inventory, a továbbiakban S-CPI) változatának segítségével. Azért egy személyiségkérdöívre esett a választás, mivel bizonyos feltételek betartása mellett ,a személyiség-kérdőívek használatának nincsenek komoly veszélyei, a belölük nyert információk az alkalmasságvizsgálat legértékesebb, leghasznosabb részei lehetnek" (Juhász 2019a, 73).

\section{ÉRTÉKESÍTŐK KIVÁLASZTÁSA SELECTION OF SALESPEOPLE}

Az elmúlt években jelentősen megváltoztak az értékesítőkkel, különösen a pénzügyi területen dolgozó értékesítőkkel szembeni elvárások. Egyre inkább tapasztalható, hogy a más területeken (pl. gépjármüértékesítés, ingatlaneladás, FMCG) már bizonyított, tehetséges üzletkötőket, értékesítési vezetőket szívesen várják a pénzügyi vállalkozások is. A pénzügyi, biztosítási tevékenység nemzetgazdasági ág HR szakembereinek véleménye szerint: „A jó képességü vezetők bankszektorba hívása és megtartása továbbra is elsődleges feladat, csakúgy, mint a jól teljesítő és tehetséges szakemberek felkutatása." (Somogyi Edit, a CIB Bank ügyvezető igazgatója, az Emberi Erőforrás Divízió vezetője), valamint „Az egyik legnagyobb kihívás a legjobb tehetségek, szakemberek megtartása, illetve megszerzése egy olyan munkaerőpiacról, amely valószínűleg az utóbbi évtized legdinamikusabb változásán megy át." - Végh József, a K\&H-csoport HR igazgatója (Csabai 2016,9).

Napjaink gyorsan változó gazdasági körülményei és feltételei egyre komolyabb követelmények elé állítják a vállalkozásokat. A piacon elért siker már nem csak a technológián és a fizikai eszközökön múlik, hanem egyre inkább a megfelelő készségekkel, tapasztalattal, tudással, elkötelezettséggel - és hozzá kell tenni, hogy megfelelő személyiséggel is - rendelkező emberi erőforrásokon (Effron et al, 2003 in Karoliny \& Poór 2017). Az értékesítők eladásmenedzsmentjének az egyik legfontosabb célja, hogy az ügynök személyes szintjére legyenek lefordítva a környezet kihívásai (pl. megfelelő motiváció), melynek hatásosságát az adott ügynök kiválasztása és személyisége is befolyásolja (Bauer \& Berács 2017). Az az alapvető problémája a hatékony üzletkötők kiválasztásának, hogy „,bár a 
vállalatok meg tudják mutatni, kik a legjobb értékesítőik, azt nem tudják megmondani, hogy miért dolgoznak ilyen kiválóan....Amit tehetnek, az a jelenlegi legjobban és leggyengébben teljesítő értékesítők tesztelése, aztán egy olyan profil megrajzolása, amely vélhetően sikeres az adott vállalat eladási környezetében" (Mitev 2016, 159).

A szervezetek esetében a kiválasztás eredménye nem csak az, hogy valakit felvesz és alkalmaz a vállalat, hanem az is, hogy vajon olyan munkavállalót vesz-e fel, aki képes lesz a munkakörét eredményesen ellátni és feladatait hatékonyan elvégezni. Mindez pedig általában csak a beillesztési folyamat végére, a próbaidő lejártára derül ki (Kozák 2015). A tanácsadók - és véleményem szerint az értékesítők - személyisége, képessége, attitüdje felértékelődik a tanácsadás és így az üzletkötés minőségében is (Veres 2017). Az üzletkötők kiválasztására „,nagy súlyt kell fektetni. Azok ugyanis, akik nem rendelkeznek a megfelelő személyiségi jellemzőkkel és képességekkel, sokkal nagyobb valószínúséggel frusztrálódnak és hagyják el a vállalatot, még mielőtt a tréningek és a tapasztalat segítségével produktívvá válhatnának." (Mitev 2016, 152). Kotler és Keller szerint „,az eladószemélyzet sikerének titka a hatékony kereskedők kiválasztása. Egy felmérés szerint az eladók legjobb 25\%-a hozza a forgalom több mint 52\%-át." (Kotler \& Keller 2016). Ma már az értékesítő személyiségének fejlesztésén is nagy hangsúly van, a vonzalomalapú sales lényege például, hogy „,nem az érződik a munkatárson, hogy el akar adni valamit, hanem az, hogy a cégét saját személyiségén keresztül igyekszik bemutatni." (Kovács 2015, 61). Hovatovább még az ügyfél személyiségének az eladó személyiségére vonatkozó hatását is vizsgálni kell (Fine \& Schumann 1992, 288).

„A külső környezeti változások és a folyamatosan átalakuló szervezeti struktúra hatására napjainkra.... felismerték, hogy a kompetenciák azonosítása, definiálása, felhasználása, mérése, rendszerezése lehet a sikeres szervezeti működés egyik záloga.” (Szabó 2020, 31). Az egyik kompetenciamodell, melyet a hazai üzletkötők esetében (is) alkalmaznak a következő kompetenciák meglétére fókuszál: problémamegoldás, üzleti tudatosság, ügyfél orientáció, meggyőzés, szóbeli- és írásbeli kommunikáció, csapatmunka, optimizmus, kezdeményezőkészség, megbízhatóság (Klein \& Kiss 2016).

\section{A RÖVIDÍTETT KALIFORNIAI PSZICHOLÓGIAI SZEMÉLYI- SÉG-KÉRDŐÍV BEMUTATÁSA PRESENTATION OF THE SHOR- TENED CALIFORNIA PSYCHO- LOGICAL INVENTORY}

Globális szinten számos kiválasztási módszert és metodikát alkalmaznak a nemzetközi nagyvállalatok emberi erőforrásokkal való gazdálkodásuk során. Sok vállalkozás állásbörzék keretén belül közvetlenül az egyetemekről szerzi be a számára szükséges munkaerőt, több nagyvállalat pedig egy központi nyilvántartást vezet a dolgozókról, melyben a demográfiai adatokon túl számos más fontos adatot is nyilvántart. Így akár a kiválasztáskor alkalmazott tesztek alapján felállított személyiségprofilt is. A nagy nemzetközi vállalatok kiválasztási gyakorlatának esetében többek között az alábbi teszteket lehet megemlíteni:

- MMPI (Minnesota Multiphasic Personality Inventory),

- $\quad$ MBTI (Meyers-Briggs Type),

- $\quad$ CPI (California Psychological Inventory),

- OPQ (Occupational Personality Questionnaire) (Poór 2009, 261).

A California Psychological Inventory, magyarul a Kaliforniai Pszichológiai Kérdőív kezdeményének tekinthető skálát elöször 1948-ban publikálta Harrison Gough, majd 1951-ben 15 skálából álló tesztet jelentetett meg a szerző. A később kialakított 18 skálából álló kérdőív a normál személyiség legfontosabb alapdimenzióinak a feltérképezésére koncentrál (még később ez kibővül 21 skálára).

A tesztet jelenlegi formájában elöször 1957-ben publikálták. A kétségbeesett amerikai társadalom egyfajta csodafegyverként tekintett a tesztre, melytől a tehetséges és kreatív személyiségek felismerését és felkarolását várták az oktatás megreformálásának révén. A teszt azóta széles körben elterjedt, „csak” az Amerikai Egyesült Államokban évente 250000 CPI válaszlapot töltenek ki. Négy földrészen, számos nyelvre lefordították, mint például: cseh, holland, francia, német, hindi, héber, olasz, japán, kínai (4 dialektus), koreai, norvég, lengyel, spanyol, svéd, tamil, török. 1973-tól használják kutatási célokra Magyarországon az ELTE Általános Pszichológia tanszékén (Oláh 1985a, 9).

A CPI olyan személyiségtulajdonságok megállapítására vállalkozik, amelyek a közösségi élet és a szociális interakciók szempontjából jelentősek. A kérdőív alkalmazhatósága rendkívül széles körü: 
üzleti és ipari területeken, pedagógiai kutatásoknál, vezetők kiválasztásánál, tanácsadó hivatalokban, antiszociális tendenciákkal rendelkező személyek vizsgálatánál egyaránt sikerrel használható. A teszt rövidített változata az S-CPI 300 olyan állítást tartalmaz, melyekre a vizsgálati személy igen-nem válaszokkal jelezheti a kérdésekkel kapcsolatos állásfoglalását. Az S-CPI a már említett 21 skálát foglalja magában, a skálák mindegyike az interperszonális viselkedés egy-egy vetületét térképezi fel. A 21 skálán kapott értékeket egy úgynevezett profillapon összesítik, a felrajzolt profil lesz az értelmezés alapja. A kérdőivet 14-70 éveseknél alkalmazhatják, csoportos és egyéni vizsgálatban egyaránt használható, átlagos kitöltési ideje 30-45 perc. Az S-CPI tesztben alkalmazott 21 skála arra szolgál, hogy átfogó képet adjon a személyek interperszonális viselkedéséről és feltárja a szociális alkalmazkodás emocionális, teljesítménymotivációs, intellektuális és morális hátterét. A 21 skálát az interpretáció megkönnyítésére Gough rendszerét követve Oláh Attila és munkatársai 4 osztályba csoportosították. „Az első osztályba sorolt skálák a dominancia-szubmisszió tengely mentén helyezik el a személyt; a második osztály skálái a felettes-én funkciók erőssége alapján, a harmadik osztály skálái az intellektuális hatékonyság és a teljesítmény motivációs háttere szerint, a negyedik osztály skálái az érdeklődés irányultságát mérve adnak információt a személy szociális viselkedéséről." (Oláh 1985a, 15-16).

A 21 skála csoportosítása a következő módon történt (Oláh 1985a, 17; Oláh 1985b, 11-12), az egyes skálák elnevezései után az eredeti elnevezések, angol nyelvből származó rövidítései találhatók:

\section{I. skála csoport:}

Az interperszonális hatékonyság, szociális ügyesség, kiegyensúlyozottság és önbizalom mutatói.

1. Dominancia (Do)

2. Státus elérésére való képesség (Cs)

3. Szociabilitás (Sy)

4. Szociális fellépés $(\mathrm{Sp})$

5. Önelfogadás (Sa)

6. Jó közérzet $(\mathrm{Wb})$

7. Szorongás (An)
II. skála csoport:

Szocializáltság, szociális érettség, felelősségtudat, kiegyensúlyozottság és a személyiség értékrendszerének a mutatói.

1. Felelősségtudat $(\mathrm{Re})$

2. Szocializáltság (So)

3. Önkontroll (Sc)

4. Tolerancia (To)

5. Énerö (Es)

6. Jó benyomás keltés (Gi)

7. Közösségiség $(\mathrm{Cm})$

III. skála csoport:

A teljesítmény motivációs hátterének (intrinzik vagy extrinzik) és az intellektuális hatékonyságnak a mutatói.

1. Teljesítményelérés konformizmus útján (Ac)

2. Teljesítményelérés függetlenség útján (Ai)

3. Intellektuális hatékonyság (Ie)

IV. skála csoport:

$\mathrm{Az}$ érdeklődés irányultságának, a személyiség plaszticitásának, az intellektus jellemzőinek mutatói.

1. Pszichológiai érzék (Py)

2. Empátia (Em)

3. Flexibilitás $(\mathrm{Fx})$

4. Nőiesség $(\mathrm{Fe})$.

A pénzügyi, biztosítási tevékenység nemzetgazdasági ág üzletkötőinek 1000 fős mintáján korábban még nem végeztek felmérést a S-CPI teszt segítségével. A jelen kutatáshoz kapcsolódó 21 dimenzió átlageredményeit már publikáltam (1. ábra). Az ábráról leolvasható adatokon túl elmondható, hogy az üzletkötőknek ,az S-CPI tesztben elért eredményei a standardizált eredményekhez képest nemenként a következő eltéréseket hozták: nőknél a Státus elérésére való képesség, az Énerő, a Jó benyomás keltés, valamint a Közösségiség esetében, a férfiaknál (szintén) a Státus elérésére való képesség, valamint a Pszichológiai érzék esetében elért eredmények statisztikailag igazolható mértékben nem térnek el a standard értékektöl. Az összes többi esetben azonban igen.” (Juhász 2019c, 184). 
1. ábra: A válaszadók S-CPI profiljának átlagértékei (nyerspontérték)

Figure 1. Mean values of the respondents' S-CPI profile (raw point value)

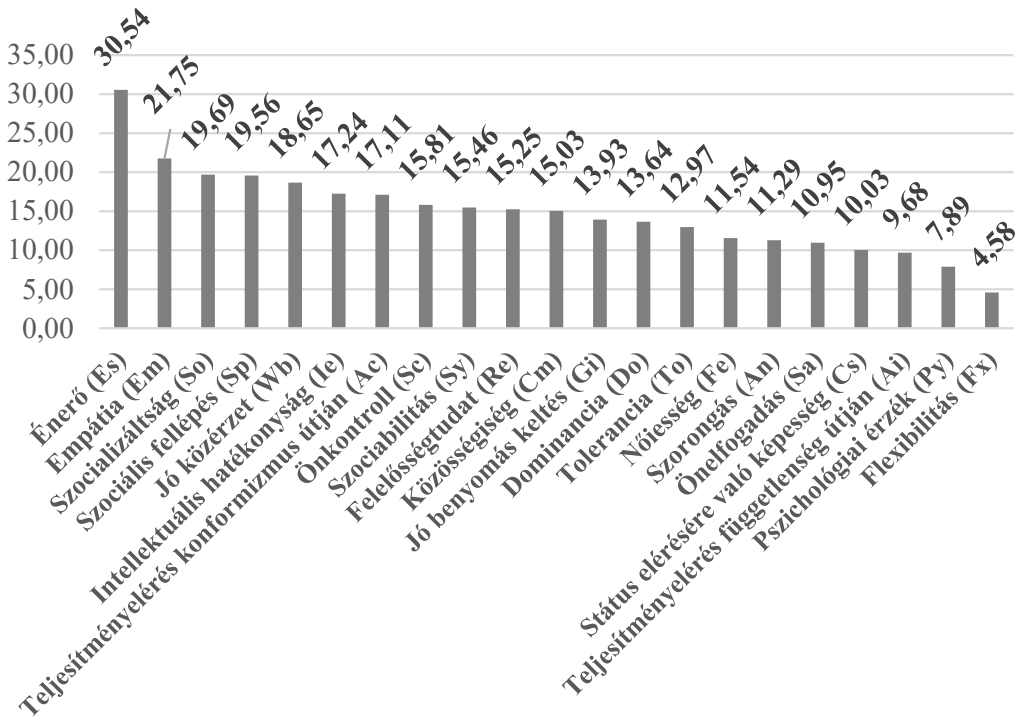

Forrás: Juhász 2019c, 184

\section{A KUTATÁS MÓDSZERTANA: A VIZSGÁLAT ALANYAI, MÉ- RÉS, ADATGYÜJTÉS, ELEMZÉS ${ }^{1}$ RESEARCH METHODOLOGY: THE SUBJECTS OF THE INQUI- RY, MEASUREMENT, DATA COL- LECTION, ANALYSIS}

A kutatás módszertanának bemutatása előtt szeretném megjegyezni, hogy a jelen tanulmányhoz kapcsolódó doktori kutatás vizsgálati körülményei és módszertana szükségszerűen megegyezik más, a doktori kutatáshoz kapcsolódó publikációk vizsgálati körülményeivel és módszertanával, további komponensei azonban nem.

\section{A vizsgálat alanyai}

\section{The subjects of the inquiry}

A vizsgálat alanyai a jelenleg pénzügyi területen, azon belül is értékesítői munkakörben dolgozó munkavállalók. A bankoknál, biztosító társaságoknál, lakástakarékpénztáraknál, pénzügyi tanácsadóknál, valamint faktorcégeknél, lízingcégeknél, takarékszövetkezeteknél és tőzsdei vállalatoknál dolgozó foglalkoztatottak alapsokaságából az ügyfelekkel közvetlenül, személyes kontaktusba kerülö értékesítők kerültek a kutatás középpontjába.

\section{Mérés, adatgyüjtés}

\section{Measurement, data collection}

A mérés során az alábbiakban felsorolt - zárt és nyitott kérdésekre épülő - részekből álló kérdőívet töltötték ki a vizsgálati személyek:

1. Alap- és demográfiai adatok,

2. Kaliforniai Pszichológiai Kérdőív rövidített változata (S-CPI).

A vizsgálati alanyok on-line az internet segítségével dolgoztak, kiküszöbölve így a papír alapú vizsgálatfelvételnél esetlegesen felmerülö téri- és időbeli korlátokat. Törekedtem arra, hogy a kérdőív elsősorban egyszerü „egérhasználattal” kitölthető legyen. A kérdésekre adható válaszok többségét a válaszadók egyszerü „kattintással” vagy a legördülő menüből történő szelektálással jelölték meg. Néhány kérdésnél azonban elkerülhetetlen volt a billentyüzet használta, mint például a legmagasabb 
fokú szakmai végzettség vagy a munkakör pontos megnevezése (ha nem szerepelt a felsoroltak között).

A vizsgálat során intim, személyes jellegű kérdések is felvételre kerültek, ezért az egyes kérdésekre adott konkrét válaszok és azok eredményei szigorúan a vizsgálati alanyok személyes adataiként, bizalmasan kezeltem. Amennyiben a válaszadók kérték akkor személyre szabott kiértékelést kaphattak az egyéni vizsgálati eredményeikről. Az eredményeket e-mailben, excel fájl formájában küldtem el. Kiküldtem továbbá egy 18 oldalas word dokumentum is, mely az eredmények részletes magyarázatát tartalmazta.

Az adatgyüjtés legfontosabb ismérvei: a kérdőív megszerkesztésére, kialakítására, tesztelésére, javítására és véglegesítésére 2016. november és december hónapjaiban került sor. A kérdőív on-line módon 2016. december 14-én, 11:14 órakor lett közzétéve és 2017. július 20-án, 08:13 órakor került lezárásra. A mintavétel a nem véletlen mintavételi eljárások közül, a hólabda-mintavételi eljárás révén történt. Igénybe lett véve volt és jelenlegi kollégáim, munkatársaim, hallgatóim illetve rokonaim, barátaim és ismerőseim releváns kapcsolati tőkéje. A hólabda mintavételi eljárás lényegéből adódóan a kérdöívet már kitöltő válaszadókat is megkértem (a kérdőív linkjének számukra újbóli elküldésének segítségével), hogy javasolják a kérdőív kitöltését ismeretségi körükbe az ugyanehhez a célsokasághoz tartozó potenciális válaszadóknak. Felkerestem továbbá olyan nagyobb, a pénzügyi, biztosítási tevékenység nemzetgazdasági ághoz kapcsolódó szervezeteket és azok tagjait közvetlen vagy közvetett formában, mint a Magyar Bankszövetség, a Magyar Biztosítók Szövetsége, az Országos Takarékszövetkezeti Szövetség, a Pénzügyi Vállalkozások Országos Egyesülete, a Magyar Lízingszövetség, a Magyar Kereskedelmi és Iparkamara, a Magyar Közgazdasági Társaság.

1656 fö kezdte meg a kérdőív kitöltését. 1069 fö töltötte ki teljes egészében a kérdöívet. 1000 fó eredményei kerültek bele a véglegesített mintába, 69 fő eredményeit különböző okok (pl. nem releváns munkakör, nem releváns gazdasági ág) miatt ki kellett szürni a mintából. 584 fő kérte és kapta meg a kérdőív alapján elért eredményeit e-mailben. Budapestről és 19 magyarországi megyéből is vannak a mintában vizsgálati személyek.

A begyüjtött adatok elemzése és kiértékelése az SPSS program segítségével történt. A statisztikai próbák közül - a hipotézisben foglaltak alátámasztására a leginkább megfelelőnek látszó elemzési módszert azaz - a diszkriminanciaelemzést alkalmaztam.

\section{PÉNZÜGYI TERÜLETEN DOLGOZÓ ÉRTÉKESÍTŐK VIZSGÁLATA A RÖVIDÍTETT KALIFORNIAI PSZICHOLÓGI- AI SZEMÉLYISÉG-KÉRDŐÍV SEGÍTSÉGÉVEL TESTING OF FINANCIAL SALES ASSOCIATES USING THE SHOR- TENED CALIFORNIA PSYCHO- LOGICAL INVENTORY}

\section{Kutatói kérdés, hipotézis \\ The main question of the research pro- ject, the respective hypotheses}

Ahogy az már korábban már említésre került: a kutatás kérdőíve kitér arra, hogy az értékesítők a pénzügyek melyik területén (ágazatában) dolgoznak. Indokoltnak tünt egy olyan összehasonlító elemzés, mely arra tér ki, hogy ezen ágazatok üzletkötőit meg lehet-e különböztetni az S-CPI tesztben elért eredményeik alapján.

A fentiekből kiindulva a kutatás alapvető kérdése az, hogy vajon a bank, a biztosítás, a lakástakarékpénztár és a pénzügyi tanácsadás területén dolgozó értékesítők személyisége az S-CPI kérdőív eredményeinek tükrében jelentősen eltér-e egymástól? A kutatási kérdést mérhetővé téve, az alábbi hipotézist - és az azzal együtt az alkalmazni kívánt vizsgálati módszereket - fogalmaztam meg:

H1) A bank, a biztosítás, a lakástakarékpénztár és a pénzügyi tanácsadás terén dolgozó értékesítők személyisége az S-CPI kérdőív eredményeinek tükrében jelentősen eltér egymástól.

Hipotézisemet diszkriminanciaelemzéssel teszteltem (felhasználva a Mahalanobis-távolság mutató, a Box's M mutató, multikollineartiás vizsgálat, a Wilks'-lambda mutató, a Pearson korrelációs együttható mátrix (structure matrix) és a centroidok megjelenítésének eredményeit). 


\section{A diszkriminanciaelemzés eredményei Results of discriminant analysis}

A kutatási kérdés vizsgálatára a legjobb módszer a diszkriminanciaelemzés, ez ugyanis „arra keresi a választ, hogy mely változók alapján különböznek a csoportok egymástól” továbbá ,arra ad becslést, hogy egy megfigyelés az adott csoporthoz tartozik-e vagy sem” valamint „meghatározza a független változók lineáris kombinációját, amely a „legjobban" elkülöníti a csoportokat" (Sajtos \& Mitev 2007, 331-332)

A diszkriminanciaelemzés függő és független változók révén számol. Jelen esetben a független változók az S-CPI kérdőív dimenzióiban elért eredmények, a függő változók az egyes ágazatok.

A diszkriminanciaelemzés klasszifikációs táblázata (1. táblázat) adja a diszkriminancia elemzés legfontosabb eredményét. Kiszámításra került a véletlen kategorizálás esetén kapott elvárt találati arányt tartalmazó táblázat is a tényleges priori értékekkel (2. táblázat). A klasszifikációs táblázat a helyesen kategorizált csoporttagságok arányát mutatja meg. A sorok a függő változó kategóriáit és az azokban megfigyelt eredeti értékeket, míg az oszlopok a függő változó kategóriáiban a független változó által becsült értékeket szemléltetik. A táblázatban a tényleges találati arány (a táblázat felső részében) is megtalálható, amelynek értéke 0 és 100 százalék között mozoghat. Az értékeket nem a nullával, hanem az elvárt találati aránnyal kell összehasonlítani. A két táblázat adatai alapján leolvashatóak a tényleges találati arányok (azaz a helyesen kategorizált esetek) és a (zárójelben feltüntetett) elvárt találati arányok viszonya, melyek ágazatonként a következők: bank 40,4 \% (37,9 $\%)$, biztosítás 38,1\% (27,5\%), lakástakarékpénztár 52,1\% (20,3\%), pénzügyi tanácsadás 31,6\% $(14,4 \%)$. Megállapítható tehát, hogy a tényleges találati arányok (azaz a „posteriori valószínúségek, (melyek) azt jelzik, hogy mekkora a valószínüsége annak, hogy valaki a diszkrimináló függvény hozzá tartozó értéke alapján egy adott csoportba kerül" (Székelyi \& Barna 2008, 335-336)) minden esetben meghaladták az elvárt (priori) találati arányok értékét, már amennyiben az S-CPI kérdőív eredményei kerülnek a kategorizálás során figyelembe vételre. A három helyes találati arány összesített értékét a klasszifikációs táblázat alatti felirat mutatja, értéke: 40,9\%, ami azt jelenti, hogy az adott független változók alapján a program az esetek 40,9 százalékát tudta helyesen kategorizálni. A klasszifikációs táblázat második felében az elemzés keresztérvényességének vizsgálatára került sor, melynek lényege, hogy az elemzést a program többször elvégzi, de ez úgy történik, hogy mindig kihagyásra kerül egy-egy megfigyelés. Az esetek többségében - így most is - a keresztérvényességi százalék $(35,6 \%)$ alacsonyabb szokott lenni, azaz a találati arány csökkent egy-egy megfigyelés kihagyásával (minden egyes ágazatban csökkenés következett be). Összefoglalva tehát elmondható, hogy a diszkriminancia függvények bevonásának segítségével nagyobb találati arány várható, mintha csak a véletlen szerint kerülnének kategorizálásra az üzletkötők, igaz ez akkor is, ha a keresztérvényesség kerül vizsgálatra (kivétel a banki dolgozók esetében, ahol 0,9 \%-kal rosszabb lett ebben az esetben a találati arány a szimpla véletlentől) (Sajtos \& Mitev 2007, 346-349). 
1. táblázat: A diszkriminancia elemzés klasszifikációs táblázata

Table 1. The classification table of the discriminant analysis

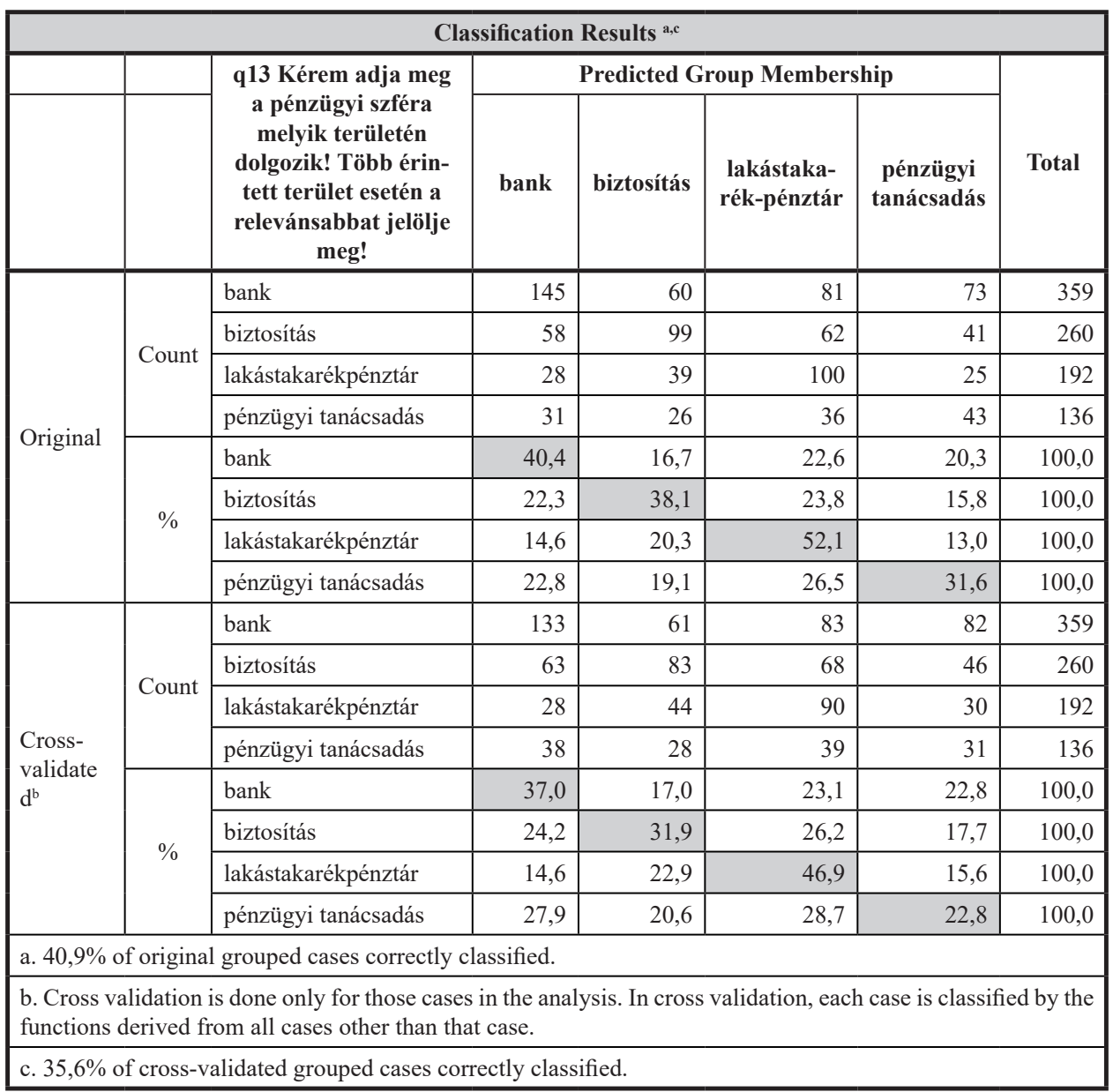

Forrás: saját kutatás alapján, saját szerkesztés az SPSS program segitségével (2021) 
2. táblázat: A véletlen kategorizálás esetén kapott elvárt (priori) találati arány

Table 2. The expected a priori score rate obtained via random categorization

\begin{tabular}{|l|c|r|c|}
\hline \multirow{2}{*}{ Megnevezés } & $\begin{array}{c}\text { Tényleges } \\
\text { elemszám }\end{array}$ & $\begin{array}{c}\text { Véletlen kategorizálás esetén } \\
\text { kapott találati arány (g1/n, ahol } \\
\text { g1=csoportnagyság, n=minta- } \\
\text { nagyság) }\end{array}$ & Teljes mintanagyság \\
\hline bank & 359 & $37,9 \%$ & 947 \\
\hline biztosítás & 260 & $27,5 \%$ & \\
\hline lakástakarékpénztár & 192 & $20,3 \%$ & \\
\hline pénzügyi tanácsadás & 136 & $14,4 \%$ & \\
\hline
\end{tabular}

Forrás: saját kutatás alapján, saját szerkesztés az SPSS program segitségével (2021)

\section{A kutatás korlátai \\ The limitations of the research}

A kutatás korlátjaiként a következőket lehet megemlíteni:

- $\quad$ az ágazat négy ágazatának (bank, biztosítás, lakástakarékpénztár, pénzügyi tanácsadás) üzletkötőiből állt rendelkezésre megfelelő elemszámú (947fö) minta a vizsgálat lefolytatásához, a többi ágazat képviselői, azok alacsony létszámú volta miatt nem kerültek be a vizsgálatba,

- érdemes lenne a faktorcégeknél, lízingcégeknél, takarékszövetkezeteknél és tőzsdei vállalatoknál dolgozó foglalkoztatottak alapsokaságából nagyobb mintavétel segítségével megismételni a vizsgálatot,

- a kutatás még a pandémia elött került lebonyolításra, érdekes eredményeket hozhatna a pénzügyi, biztosítási tevékenység nemzetgazdasági ágban jelenleg sikeresen dolgozó értékesítők személyiségjellemzőinek, illetve az ágazatok közötti jelenlegi átjárhatóságának vizsgálata.

\section{KÖVETKEZTETÉSEK, JAVASLATOK CONCLUSIONS, RECOMMEN- DATIONS}

A vizsgált minta S-CPI eredményein végzett diszkriminanciaelemzés alapján kapott diszkriminanciafüggvényekről a következőket állapítom meg:

A vizsgált, pénzügyi területen dolgozó üzletkötők mintájában az S-CPI eredményein végzett diszkriminanciaelemzés során kapott diszkriminanciafüggvények a véletlennél nagyobb valószínűséggel képesek elöre jelezni, hogy az egyes üzletkötők melyik ágazatban dolgoznak. A „legjobban” a lakástakarékpénztárakban dolgozók kategorizálhatók elö - ahol a priori és a keresztérvényességi adatok különbsége 26,6 \% - majd a pénzügyi tanácsadók $(8,4 \%)$, valamint a biztosítókban dolgozók (4,5\%). A bankok munkatársainál az előrejelzés a véletlenszerü besorolásnál rosszabb eredményt mutatott $(-0,9 \%-k a l)$. Az eredmények tükrében közel sincs olyan jelentős eltérés az egyes ágazatok üzletkötőinek S-CPI eredményei között, mely megakadályozná, hogy azok egy másik ágazatban is „,kipróbálásra” kerüljenek.

Bár a fentiek alapján a diszkriminanciafüggvények a véletlennél nagyobb valószínűséggel képesek előre jelezni, hogy az egyes üzletkötők melyik ágazatban dolgoznak, az egyes ágazatok közötti eltérés azonban olyannyira jelentéktelen, hogy a H1) hipotézist elvetem.

A fentiek alapján javaslom, hogy a vállalati döntéshozók a pénzügyi területen tevékenykedő értékesítők kiválasztásában alkalmazzák az S-CPI kérdőí- 
vet, de ne tartsanak attól, hogy egy másik ágazatban már bizonyított és a kérdőívben ,jó” eredményeket elért üzletkötőt felvegyenek a vállalathoz, mivel a kérdőívben elért eredmények alapján közel sincs olyan nagy különbség az egyes ágazatok üzletkötőinek személyisége között, mint az feltételezhető lenne!

\section{ÖSSZEFOGLALÁS SUMMARY}

Bár az értékesítés, az üzletkötés a gazdaság „motorja”, mégis még meglehetősen kevés kutatás vizsgálja az üzletszerzésben oly lényeges tényező, az értékesítő személyiségét. Az üzletkötés és üzletszerzés terén akkor lehet a legnagyobb eredményt elérni, ha azt olyan munkatársak végzik, akik egyrészről értenek választott hivatásukhoz, másrészről személyiségük lényeges vonásai megfelelnek a munkakör betöltéséhez szükséges és elvárt kritériumoknak.

Az értékesítői álláshirdetésekre jelentkező szakemberek esetében már az első személyes találkozó, interjú során fel lehet térképezni a jelölt értékeit, motivációit, személyiségét, habitusát, kompetenciáit. Amennyiben beleillik a vállalat által elvárt profilba, úgy érdemes a kiválasztást végző szakembernek tüzetesebb vizsgálatok alá vetni a jelentkezőt. Az alkalmazott vizsgálatok, tesztek eredményeinek tükrében a személyzeti-, értékesítési vezető eldöntheti, hogy érdemes-e felvenni a szervezethez az adott pályázót vagy sem. Amennyiben érdemes, akkor energiát, pénzt és időt nem sajnálva kell szakmai tudással felvértezni az új kollégát annak érdekében, hogy mindkét fél kölcsönös megelégedettségére végezze majd munkáját (Juhász 2019b, 125).
A tanulmány megírásának az volt a célja, hogy összehasonlítsa a S-CPI kérdőív segítségével a magyarországi pénzügyi, biztosítási tevékenység nemzetgazdasági ág egyes ágazatainak üzletkötőire vonatkozó eredményeit. A vizsgálati eredmények alapján arra a következtetésre jutottam, hogy nincs akkora különbség a vizsgált nemzetgazdasági ág egyes ágazataiban tevékenykedő értékesítők legfontosabb személyiségdimenziói tekintetében, mint az feltételezhető lenne. „A kutatás jövőbeli iránya lehetne egy olyan nagyobb volumenü felmérés, mely nemcsak a vizsgálat értékesítőire, hanem más nemzetgazdasági ágak üzletkötőire (pl. FMCG, gépjármükereskedelem, ingatlanértékesítés) is kiterjedne és összehasonlítási alapul szolgálhatna az egyes nemzetgazdasági ágak közötti átjárhatóságra." (Juhász 2019b, 126). 


\section{HIVATKOZÁSOK REFERENCES}

Bauer A., Berács J. (2017), Marketing, Budapest: Akadémiai Kiadó, DOI: 10.1556/9789634540076 https://mersz.hu/hivatkozas/dj204m_book1\#dj204m_book1 (Utolsó letöltés: 2020.10 .07$.

Bauer A., Mitev A. (2016), „Az értékesítővé válás folyamata", Vezetéstudomány, 47(3), 23-56.

Csabai K. (2016), Munkaerö kerestetik, HR Plusz - változás, generációk, technológia, jövö, Budapest: HVG Kiadó Zrt.

Effron, M., Gandossy, R. and Goldsmith, M. (2003), Managing Human Resources in the 21st Century, Wiley, Hoboken.

Fine, L. M. and Schumann, D. W. (1992), "The Nature and Role of Salesperson Perceptions: The Interactive Effects of Salesperson / Customer Personalities", Journal of Consumer Psychology, 7(3), 285-296. DOI: https://doi.org/10.1016/ S1057-7408(08)80040-X (Utolsó letöltés: 2020.10.07.)

Juhász I. (2014a), „Kínai munkavállalók motiválásának alternatívái - Hofstede kulturális dimenzióinak tükrében", Vezetéstudomány, XLV(10), 58-67. http://eds.b.ebscohost.com/ eds/pdfviewer/pdfviewer?vid=1\&sid=74588c62 -ad1e-48ae-aba9-0d1d2ea40feb\%40pdc-v-sessmgr03, (Utolsó letöltés: 2021.02.11.)

Juhász I. (2014b), „Kínai munkavállalók motiválásának vezetői kihívásai - kulturális sajátosságok, mint korlátok és mint lehetőségek", Marketing \& Menedzsment, 48(2) 71-82. https://journals.lib.pte.hu/index.php/mm/article/ view/995/863, (Utolsó letöltés: 2021.02.11.)

Juhász I. (2019a), „Pályaalkalmassági vizsgálatok és alkalmazásuk az emberi erőforrások kiválasztásában - különös tekintettel a személyiségtesztekre", Munkaügyi Szemle, 62(5), 65-74. http:// www.munkaugyiszemle.hu/palyaalkalmassagi-vizsgalatok-es-alkalmazasuk-az-emberi-eroforrasok-kivalasztasaban-kulonos, (Utolsó letöltés: 2021.02.01.)

Juhász I. (2019b), A versenyszféra pszichológiai elvárásai a jelenkor üzletkötőivel szemben különös tekintettel a pénzügyi, biztositási tevékenység nemzetgazdasági ágra, Miskolc: Miskolci Egyetem, Vállalkozáselmélet és Gyakorlat Doktori Iskola. DOI: 10.14750/ME.2019.024

Juhász I. (2019c), „Pénzügyi területen dolgozó értékesítők személyiségvizsgálata", Pénzügyi Szemle, 64(2), 175-190. https://www. penzugyiszemle.hu/hu/penzugyi-szemle-folyoirat-archivalt-cikkek/penzugyi-teruleten-dolgozo-ertekesitok-szemelyisegvizsgalata, (Utolsó letöltés: 2021.07.13.)
Karoliny M., Poór J. (2017), „Bevezetés”, in Karoliny M., Poór J. (szerk.), Emberi eröforrás menedzsment kézikönyv - Rendszerek és alkalmazások, Budapest: Wolters Kluwer Hungary Kft., 19-22.

Klein, S., Kiss, J. (2016), Az értékesitök értéke, http://www.shl.hu/dokumentumtar, (Utolsó letöltés: 2016.09.22.)

Kotler, P. and Keller, K. L. (2016), Marketingmenedzsment, Budapest: Akadémiai Kiadó. DOI: 10.1556/9789630597784 https://mersz.hu/hivatkozas/dj183m_book1\#dj183m_book1 (Utolsó letöltés: $2020 . \overline{10.07}$.)

Kovács Á. L. (2015), „Hatásvadászok”, Figyelö, 2015(14), 60-61.

Kozák A. (2015), Munkahelyi beillesztés nagyvállalati környezetben, Debrecen: Debreceni Egyetem, Ihrig Károly Gazdálkodás- és Szervezéstudományok Doktori Iskola. Disszertáció.

Mitev A. Z. (2016), „Toborzás és kiválasztás”, in Bauer A., Mitev A. Z. (szerk.), Eladásmenedzsment, Budapest: Akadémiai Kiadó, 151-166. DOI: 10.1556/9789630597876 https://mersz. hu/hivatkozas/dj160e_book1\#dj160e_book1 (Utolsó letöltés: 2020.10.07.)

Oláh A. (1985a), Pszichológiai tanácsadás a pályaválasztásban - A California Psychological Inventory (CPI) röviditett változatának ismertetése, Budapest: Módszertani Füzetek, 32. Országos Pedagógiai Intézet.

Oláh A. (1985b), A Kaliforniai Pszichológiai Kérdöiv (California Psychological Inventory - CPI) tesztkönyve, Budapest: Munkalélektani Koordináló Tanács Módszertani Sorozata, Munkaügyi Kutatóintézet.

Poór J. (2009), Nemzetközi emberi eröforrás menedzsment, Budapest: CompLex Kiadó Jogi és Üzleti Tartalomszolgáltató Kft.

Sajtos L., Mitev A. (2007), SPSS kutatási és adatelemzési kézikönyv, Budapest: Alinea Kiadó.

Szabó Sz. (2020), Kompetencialapú emberierőforrás-gazdálkodás, Budapest: Nemzeti Közszolgálati Egyetem, Közigazgatási Továbbképzési Intézet. https://nkerepo.uni-nke.hu/xmlui/ bitstream/handle/123456789/15664/Kompetenciaalapu\%20emberieroforras-gazdalkodas. pdf;jsessionid=202FDE95274FEEF378996F0CF7995E0E?sequence=1 (Utolsó letöltés: 2021.07.13.)

Székely M., Barna I. (2008), Túlélőkészlet az SPSShez - Többváltozós elemzési technikákról társadalomkutatók számára, Budapest: Typotex Elektronikus Kiadó Kft.

Veres Z. (2017), A szolgáltatásmarketing alapkönyve, Budapest: Akadémiai Kiadó. DOI: 10.1556/9789630597395 https://mersz.hu/ hivatkozas/dj253asza_book1\#dj253asza_book1 (Utolsó letöltés: 2020.09.28.) 


\section{The exploration of segmental interchangeability among the brokers and salespersons of the finance and insurance sector}

\section{THE AIM OF THE PAPER}

Relying on a sample of 1000 brokers and salesperson employed in the finance and insurance sector, the study aims to demonstrate that the personality of those working in such fields as banking, insurance, building societies, and financial consultancy differ according to the shortened version of the California Psychological Inventory (Hypothesis H1).

\section{METHODOLOGY}

The inquiry primarily focuses on the finance sector, especially brokers or salespersons employed by banks, insurance companies, building societies and financial consultancy firms. The study utilized an Internet-based on-line questionnaire, which was filled in anonymously. The sample was gathered by one of the non-probability or non-random methods, the snowball approach. The obtained data was analysed and evaluated by the help of the SPSS program making a discriminant analysis possible as well.

\section{MOST IMSPORTANT RESULTS}

The discriminant analysis performed at the sample of brokers or salespersons working in the segment of the financial sector under inquiry facilitated the construction of discriminant functions. The given functions are capable of identifying with a greater than random probability the sector in which the respective broker or salesperson works. The findings also indicate that the differences in the personality of brokers and sales personnel working in the banking and insurance sector identified by the shortened version of the California Psychological Inventory are not significant enough to prevent them from working in other sectors.

\section{RECOMMENDATIONS}

Since the questionnaires reveal no significant difference between the personalities of brokers and salespersons working throughout the given segments, I suggests that HR managers, candidate selection experts, and company decision makers should consider hiring those applicants, who have already proven themselves in another segment of the finance and insurance sector (subject to meeting other hiring requirements).

Keywords: finance, salespersons, personality, workforce-selection, aptitude test 